\title{
Alterations in the intestinal wall due to protein malnutrition in rats. Evaluation of the rupture strength and the tissue's collagen ${ }^{1}$
}

\author{
Alterações da parede intestinal na carência de proteína no rato. Avaliação da força de ruptura e \\ do colágeno tecidual
}

\author{
Victor Nakajima ${ }^{\mathrm{I}}$, Shoiti Kobayasi ${ }^{\mathrm{II}}$, Luís Eduardo Naresse ${ }^{\mathrm{III}}$, Celso Vieira de Souza Leite ${ }^{\mathrm{III}}$, Paulo Roberto Curi ${ }^{\mathrm{IV}}$, Jair Cortez \\ Montovaniv \\ ${ }^{\mathrm{I}} \mathrm{MD}$, Assistant Professor, Department of Otorrinolaryngology, Head and Neck Surgery, Botucatu Medical School, Sao Paulo State University (UNESP), \\ Brazil. \\ ${ }^{\text {II }} \mathrm{PhD}$, Chairman Full Professor, Department of Surgery, Botucatu Medical School, UNESP, Brazil. \\ III MD, PhD, Assistant Professor, Department of Surgery, Botucatu Medical School, UNESP, Brazil. \\ IV PhD, Full Professor, Department of Bioestatistical, Bioscience Institute of Botucatu, UNESP, Brazil. \\ ${ }^{v} \mathrm{MD}, \mathrm{PhD}$, Full Professor, Department of Otorrinolaryngology, Head and Neck Surgery, Botucatu Medical School, UNESP, Brazil.
}

\begin{abstract}
Purpose: To study the effect of protein malnutrition on the intestinal wall of rats by evaluating alterations in the rupture force and dosing tissue collagen in the ileum and distal colon. Methods: One hundred and twenty rats, that had an average weight of $100 \mathrm{~g}$, were used. They received water and a standard diet with $20 \%$ protein during 7 days for adaptation to the diet itself and to environmental conditions. After that period, the animals were randomly distributed in two groups of 60 rats each: Group 1 - the animals received a control diet with $20 \%$ casein for 21 days; Group 2 - hypoprotein diet with 2\% casein for 21 days. After the adaptation period, 12 animals of each group were sacrificed at 5 moments: the beginning of experimental period (M0), $4^{\circ}$ day (M1), $7^{\circ}$ day (M2), $14^{\circ}$ day (M3) and $21^{\circ}$ day (M4). The diet to the other rats was maintained until the last sacrifice. The following variables were evaluated: body weight, blood albumin rate, tissue's hydroxyproline, hydroxyproline/total protein ratio and rupture strength in the intestinal wall of the ileum and the distal colon. Results: It was observed that the rupture strength in the ileum segment and distal colon was lower in malnourished animals (Group 2); the loss of mechanical resistance was higher in the distal colon segment than in the ileum probably due to the smaller concentration of tissue collagen in the distal colon. Conclusion: Protein malnutrition induces the loss of mechanical resistance of the ileum and distal colon and may be associated with a smaller percentage of collagenous tissue formation in the intestinal wall.

Key words: Protein Malnutrition. Anastomosis, Surgical. Tensile Strength. Collagen. Rats.
\end{abstract}

\section{RESUMO}

Objetivo: Avaliar o efeito da desnutrição protéica na parede intestinal do rato através da medida de força de ruptura e dosagem do colágeno tecidual no íleo e cólon distal. Métodos: Foram utilizados 120 ratos, pesando em média $100 \mathrm{~g}$, que receberam durante 07 dias uma dieta padrão, contendo $20 \%$ de caseína para adaptação dos animais as condições do biotério. Após esse período os animais foram divididos em dois grupos de 60, o controle denominado grupo um que recebeu a dieta padrão, e o grupo teste denominado grupo dois, que recebeu dieta hipoprotéica contendo $2 \%$ de caseína. Os dois grupos receberam suas respectivas dietas por um período de 21 dias. Após esse período iniciou-se o sacrifício seqüencial dos animais em ambos os grupos, em número de 12 animais em cada momento, correspondendo ao dia Zero (MO), $4^{\circ}$ dia (M1), $7^{\circ}$ dia (M2), $14^{\circ}$ dia (M3), e $21^{\circ}$ dia (M4) sendo mantida a mesma dieta até o final do sacrifício. Em cada momento foram avaliados o peso corpóreo, albumina sanguínea, hidroxiprolina tecidual, relação hidroxiprolina/ proteína tecidual e a força de ruptura no segmento ileal e cólico dos animais. Resultados: Observou-se que a força de ruptura do segmento ileal e do cólon distal foi menor nos animais desnutridos (Grupo 2). A perda da resistência mecânica foi maior no segmento do cólon distal do que no segmento ileal, provavelmente pela menor concentração do colágeno tecidual no cólon distal. Conclusão: A desnutrição protéica induz a diminuição da resistência mecânica no íleo e no cólon distal associado a diminuição do colágeno tecidual na parede intestinal.

Descritores: Desnutrição Proteica. Anastomose Cirúrgica. Resistência à Tração. Colágeno. Ratos.

${ }^{1}$ Research performed at Technical Surgery and Experimental Surgery Laboratory, Surgery and Orthopedics Department, Botucatu Medical School, Sao Paulo State University (UNESP), Brazil. 


\section{Introduction}

Malnutrition is regarded as a serious problem nationwide and, as a result, nutritional deficiencies have been broadly studied in the experimental field ${ }^{1-2}$.

The incidence of malnutrition in the hospitalized population is of 30 to $50 \%$, and the frequency at which malnutrition occurs in this population is relatively constant despite the nature of the disease and the patient's social and economic status. This fact stems from the decrease in food ingestion, either due to organic modification resulting from a basic disorder or by the quality and amount of food ingested by the population.

Malnutrition affects the progression of surgical wounds, thus favoring anastomosis dehiscence and infection in the peritoneal cavity ${ }^{5-6}$, which may result in patient's high morbidity and mortality rates. Dehiscence of anastomoses in the large intestine in particular is a frequent complication that is associated with high mortality ${ }^{7}$ rates while those related to dehiscence of ileal anastomoses are low $^{8}$. Nevertheless, most experimental studies focus on cicatrization under normal experimentation conditions when, in the clinic, various adverse factors are associated with the dehiscence of intestinal anastomosis, among them the malnutrition ${ }^{9-10}$.

Adverse malnutrition events certainly play an important modular role on the biological response to surgical aggression. Studies have shown the decrease in skin and abdominal scar mechanical resistance in rats ${ }^{3}$ as a result of alterations in fibroplasia and collagen synthesis ${ }^{7-5}$ in addition to alterations in osmotic pressure, thus producing residual edema ${ }^{7}$.

One of the models to study such alterations is the investigation on rupture strength measurements and hydroxyproline dosage in the cicatrization of the large intestine and distal colon in animals ${ }^{7}$. However, until nowadays, there have not been well outlined reports on the evaluation of the deleterious effects of protein malnutrition on the intestinal wall of rats, which is an essential parameter when the study of intestinal cicatrization is intended. Hence, this study aims to evaluate alterations in the cicatrization of the digestive system, ileal segment and distal colon by analyzing intestinal rupture strength in rats.

\section{Methods}

One hundred and twenty Wistar rats weighing from 90 to 110 grams were used. The animals were supplied by the animal colony of the Botucatu Campus - UNESP. All the animals received water and a diet with $20 \%$ protein (control diet) ad libitum for a 7-day period for adaptation to the diet itself as well as to environmental conditions of the Technical Surgery and the Experimental Surgery Laboratory of the Surgery and Orthopedics Department, Botucatu School Medicine - UNESP. A diet standardized by the nutrition group of the Department of Medical Clinic and of the Department of Pathological Anatomy of the Botucatu School of Medicine - UNESP was utilized1. After this phase, the animals were randomly divided into two groups: G1, the control group (60 rats), received a control diet containing $20 \%$ casein, and G2 (60 rats) was given a hypoprotein diet with $2 \%$ casein. After the adaptation period, 12 animals of each group were sacrificed at 5 moments: at the beginning of the experimental phase (MO), $4^{\circ}$ day (M1), $7^{\circ}$ day (M2), $14^{\circ}$ day (M3) and $21^{\circ}$ day (M4). The diet to the other rats was maintained until the last sacrifice.
The animals were examined daily, and their weigh, hair loss, edema, diarrhea, behavioral alterations and aggressiveness increase were observed. On the days of sacrifice, each animal was weighed and anesthetized with intraperitoneal sodium pentobarbital at a dose of $30 \mathrm{mg} / \mathrm{Kg}$, three $\mathrm{ml}$ of whole blood was taken by transcardiac puncture, using a $5 \mathrm{ml}$ sering with a $25 \times 8$ needle.

After this proceeding, a large median laparotomy was performed to exposure the abdominal cavity. Segment with $1.0 \mathrm{~cm}$ in length of the distal colon and of the ileum were resected at approximately $5.0 \mathrm{~cm}$ of the ileocecal valve.

Immediately after the previous procedure, the intestinal segments, ileum and distal colon, were transferred to a container with saline solution at a temperature of $37^{\circ} \mathrm{C}$ and papaverine hydrochloride $(250 \mathrm{mg} / \mathrm{l})$ and then kept in warm bath for 30 minutes. The intestinal rupture strength was evaluated either. Following that, the intestinal segment samples were weighed and conditioned in foil for later biochemical dosage of hydroxyproline and total protein.

In order to asses the rupture strength of the intestinal segments, the apparatus and technique described by Naresse et al. ${ }^{9}$ were used.

Total serum albumin was dosed by the bromocresol green method using the blood collected at the moment of sacrifice of each animal.

Tissue's protein was quantified according to the methodology described by Lowry et al. ${ }^{11}$. Total tissue hydroxyproline was determined in accordance with the methodology by Bergman and Loxley ${ }^{12}$ and modified by Angeleli et al. ${ }^{13}$.

The hydroxyproline / protein ratio was used as a reference in order to assess the collagen proportion of the intestinal tissue protein component.

The variables in each of the experimental groups and at the different studied moments were statistically analyzed by calculating the means (x), standard deviation(s) and the variation coefficient (VC). Factorial variance analysis was used for calculating the linear $(r)$ and determination $\left(r^{2}\right)$ correlation coefficients. Correlations between groups 1 and 2, and between the semi-groups were performed at each sacrifice moment.

Analysis of Variance of One-Way Layout in a Factorial Scheme was used for the statistical analysis of the obtained data. The statistics, F values and their respective levels of significance (p) were calculated for each tested hypothesis. Whenever $\mathrm{p}<0.05$, the null hypothesis was rejected and the contrasts between mean pairs were performed by calculating the minimum significant difference by the TUKEY method. In order to reproduce rupture strength measurements by the extensometer, regression analysis was used.

\section{Results}

The animals in the hypoproteic group became aggressive during the first observation week and apathetic at the other experimental moments.

The mean and the standard deviation $(\mathrm{x} \pm \mathrm{s} /)$ for the body weight of all animals was $334 \pm 101 \mathrm{~g}$. And in groups 1 and 2 at the experimental moments were respectively M0 (281 $\pm 20 ; 115 \pm 18)$; M1 (295 $\pm 36 ; 103 \pm 9) ;$ M2 (315 $\pm 23 ; 99 \pm 10) ;$ M3 (385 \pm 27 ; $102 \pm 13)$; M4 (396 $\pm 26 ; 88 \pm 14)$.

The statistical analysis showed $\mathrm{F}=48.76$ and $\mathrm{p}<0.01$ when comparing the groups and moments with one another. This 
can also be observed when assessing weight in relation to the diets correlated with treatment and time (moment) with $\mathrm{F}=326.33$ $(\mathrm{p}<0.01)$ and $\mathrm{F}=28.20(\mathrm{p}<0.01)($ Figure 1$)$.

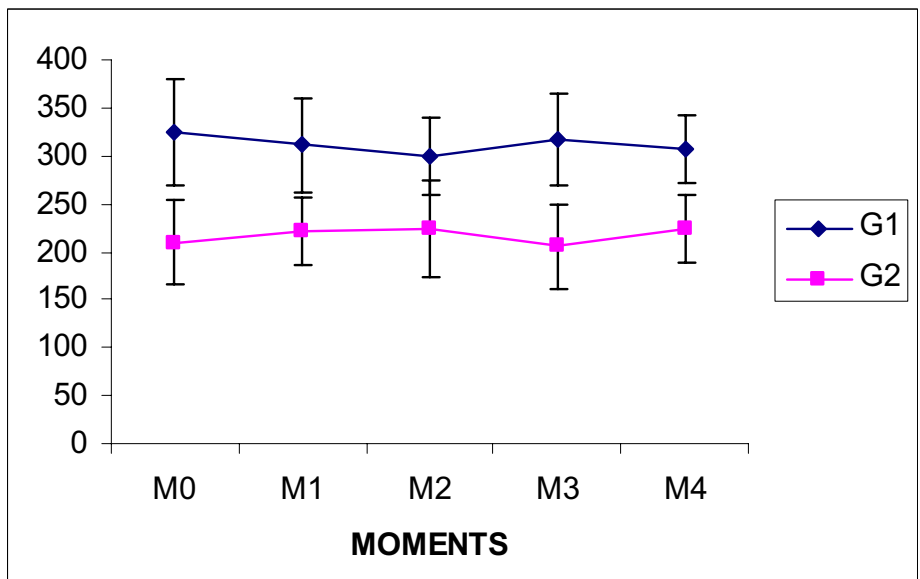

FIGURE 1 - Mean body weight for groups 1 and 2 at the experimental moments

The mean values and standard deviations for albumin in groups 1 and 2 at the moments were respectively M0 (4.3 \pm 0.3 ; $2.1 \pm 0.3), \mathrm{M} 1(4.4 \pm 0.4 ; 2.1 \pm 0.3), \mathrm{M} 2(4.5 \pm 0.3 ; 2.1 \pm 0.2), \mathrm{M} 3$ $(4.6 \pm 0.3 ; 2.3 \pm 0.2)$, M4 $(4.8 \pm 0.4 ; 2.9 \pm 0.4)$, with a general mean of 4.5 and 2.2 (Figure 2).

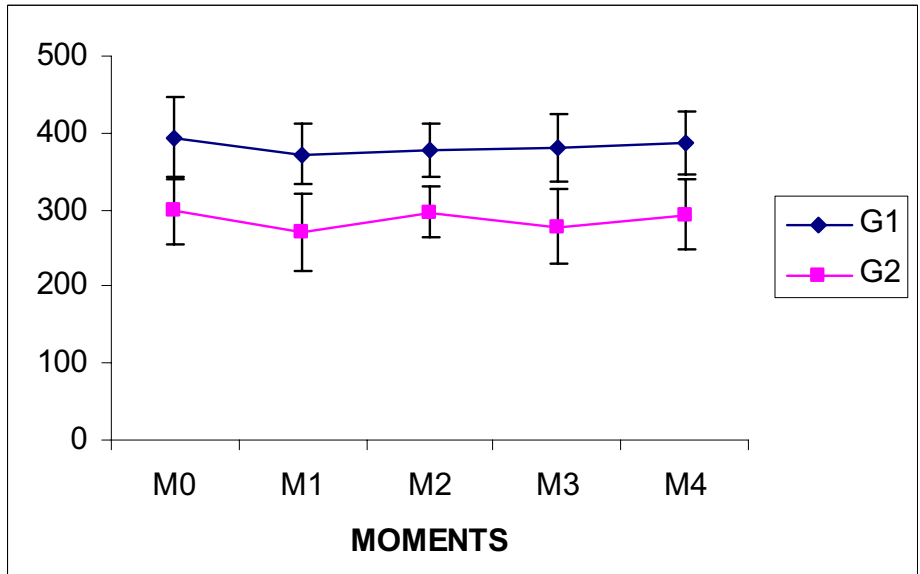

FIGURE 2 - Mean values for serum albumin concentration (g/100ml) of animals in groups 1 and 2 at the experimental moments

As regards treatment effect for group 1 versus $2, \mathrm{~F}=$ $1490.96(p<0.01)$ was observed as well as $F=5.27(p<0.05)$ for time effect, thus showing a significant albumin difference between the two groups.

Hydroxyproline concentration in the ileal segment at the moments was M0 $(324 \pm 56 ; 210 \pm 44), M 1(311 \pm 50 ; 221 \pm 36)$, M2 (300 $\pm 40 ; 223 \pm 50) ;$ M3 (316 $\pm 48 ; 206 \pm 44) ;$ M4 (307 \pm 35 ; $224 \pm 35$ ), with a general mean of 312 and 217 respectively. As regards the distal colon, the values found were M0 $(394 \pm 53 ; 299$ $\pm 43)$, M1 (372 $\pm 40 ; 270 \pm 51) ;$ M2 (378 $\pm 34 ; 297 \pm 33)$; M3 (381 $\pm 43 ; 277 \pm 49)$; M4 $(386 \pm 41 ; 294 \pm 45)$, with a general mean of 382 for the animals in group 1 and 287 for those in group 2 (Figures 3 and 4).

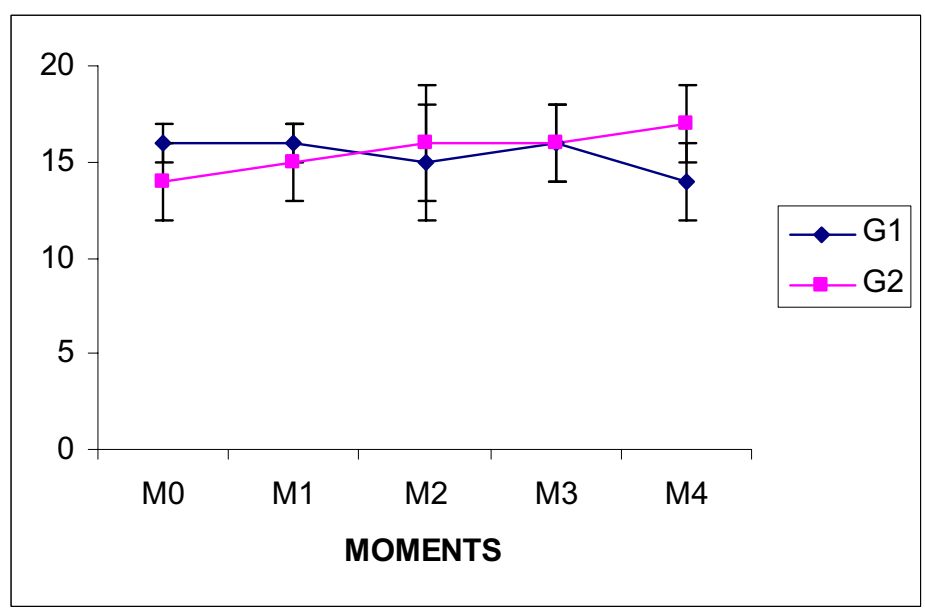

FIGURE 3 - Mean values for hydroxyproline concentration $(\mu \mathrm{g} / 100 \mathrm{mg}$ of tissue) of samples for the ileal segment in the two groups at the experimental moments

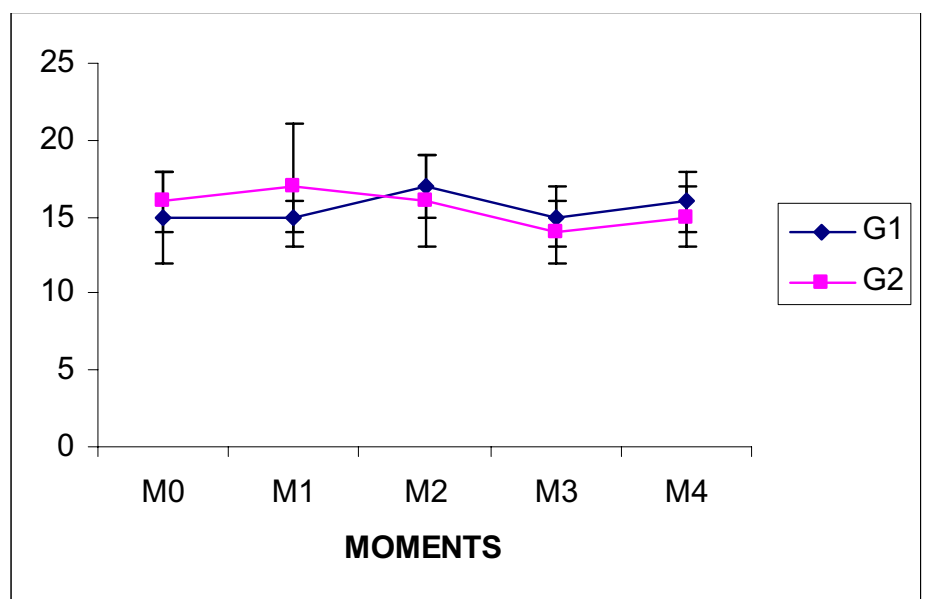

FIGURE 4 - Mean values for hydroproline concentration (mg/100 mg of tissue) of samples for the distal colon segment in the two groups at the experimental moments

When comparing the two groups as regards as regards treatment in the ileal segment, it was observed that $\mathrm{F}=137.04$ and $\mathrm{p}<0.01$.

The findings for total tissue protein in the ileal segment for the groups 1 and 2 at the different moments showed to be as follows: M0 (16 $\pm 1 ; 14 \pm 2), \mathrm{M} 1(16 \pm 1 ; 15 \pm 2)$; M2 $(15 \pm 3 ; 16$ $\pm 3)$, M3 (16 $\pm 2 ; 16 \pm 2)$, M4 $(14 \pm 2 ; 17 \pm 2)$, general average of 15 and 16 , respectively. As to the distal colon, the following were observed for the moments: M0 $(15 \pm 3 ; 16 \pm 2)$, M1 $(15 \pm 1 ; 17 \pm$ 4), M2 (17 $\pm 2 ; 16 \pm 3)$, M3 (15 $\pm 2 ; 14 \pm 2)$, M4 (16 $\pm 2 ; 15 \pm 2)$, with general mean of 15 and 16 for the animals in groups 1 and 2, respectively. These data show us that there is no significant relationship between the groups and their moments for this variable (Figures 5 and 6). 


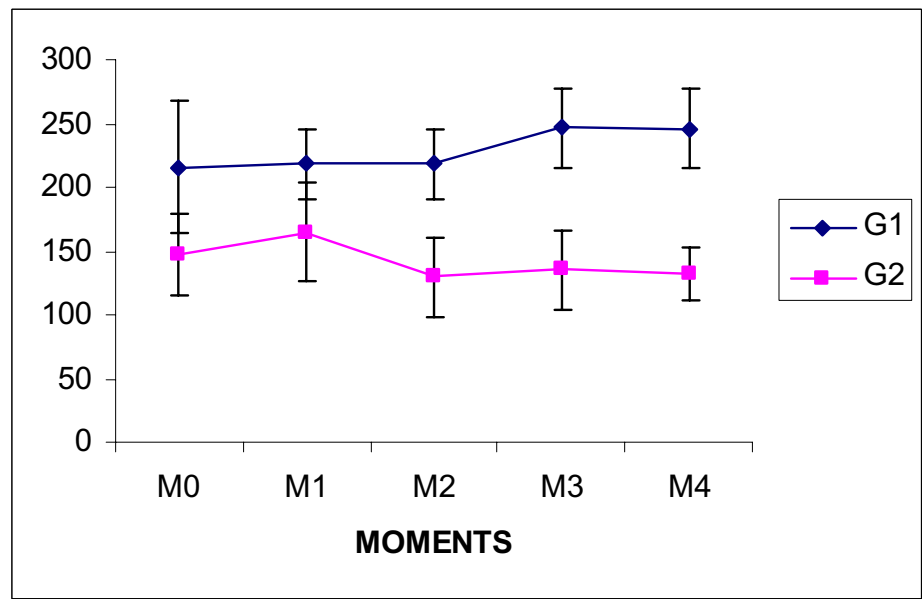

FIGURE 5 - Mean values for protein concentration ( $\mathrm{mg} / 100 \mathrm{mg}$ of tissue) of samples for the ileal segment in the two groups at the experimental moments

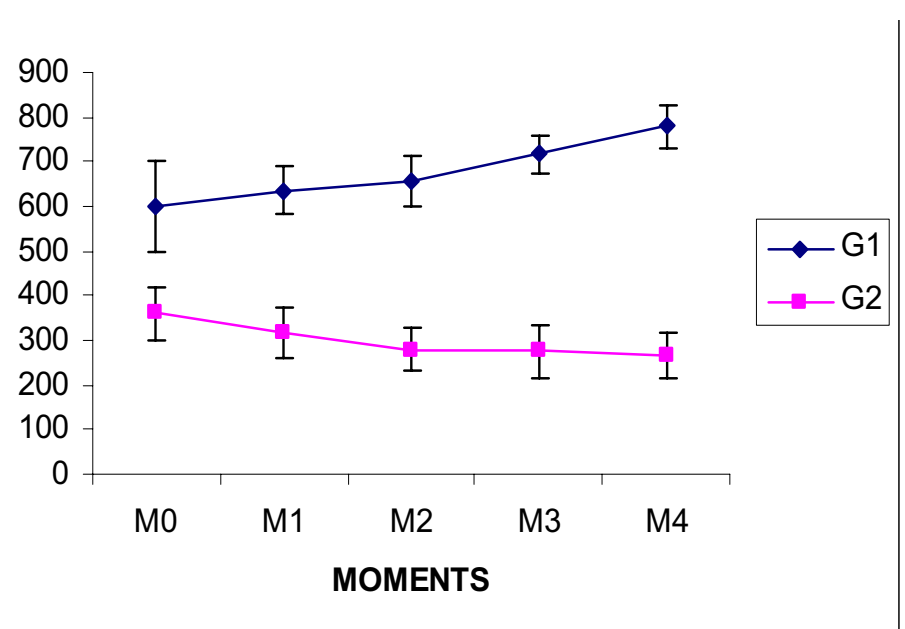

FIGURE 6 - Mean values for protein concentration (mg/100mg of tissue) of samples for the distal colon in the two groups at the experimental moments
The total hydroxyproline / protein ratio $(\mu \mathrm{m} / \mathrm{mg})$ in samples of the ileal and colon segments (mean and standard deviation) had no significant alterations between the two groups $(p>0.05)$.

When evaluating the rupture strength variable in the groups, the results found in the ileal segment for animals in groups 1 and 2 were respectively: M0 (216 $\pm 51 ; 147 \pm 32), \mathrm{M} 1(218 \pm 28 ; 165 \pm 38)$, M2 $(218 \pm 27 ; 130 \pm 31), M 3(247 \pm 31 ;$ $135 \pm 31)$, M4 $(246 \pm 31 ; 132 \pm 21)$, general mean of 228 and 142 . It was observed a significant treatment effect $(\mathrm{F}=198,96 \mathrm{p}<0,01)$, finding values for the control group higher than for the test group. However, there was no difference in the various moments studied in the two groups, so the time didn't have a significant influence.

These findings were similar when we studied rupture strength in the distal colon: M0 (599 $\pm 102 ; 360 \pm 58)$, M1 (636 $\pm 53 ; 317 \pm 54)$, M2 $(656 \pm 56 ; 280 \pm 46)$, M3 (717 $\pm 42 ; 275 \pm 59)$, M4 (779 \pm 48 ; $266 \pm 53)$, with a general mean of 676 and 300 for the animals in groups 1 and 2, respectively. In this part of the intestine, the statistical analysis showed a significant interaction in relation to the treatment $(\mathrm{F}=1211,9 \mathrm{p}<0,01)$ and to the group $(\mathrm{F}=18,87 \mathrm{p}<0,01)$, with higher levels in the control group (Figures 7 and 8).

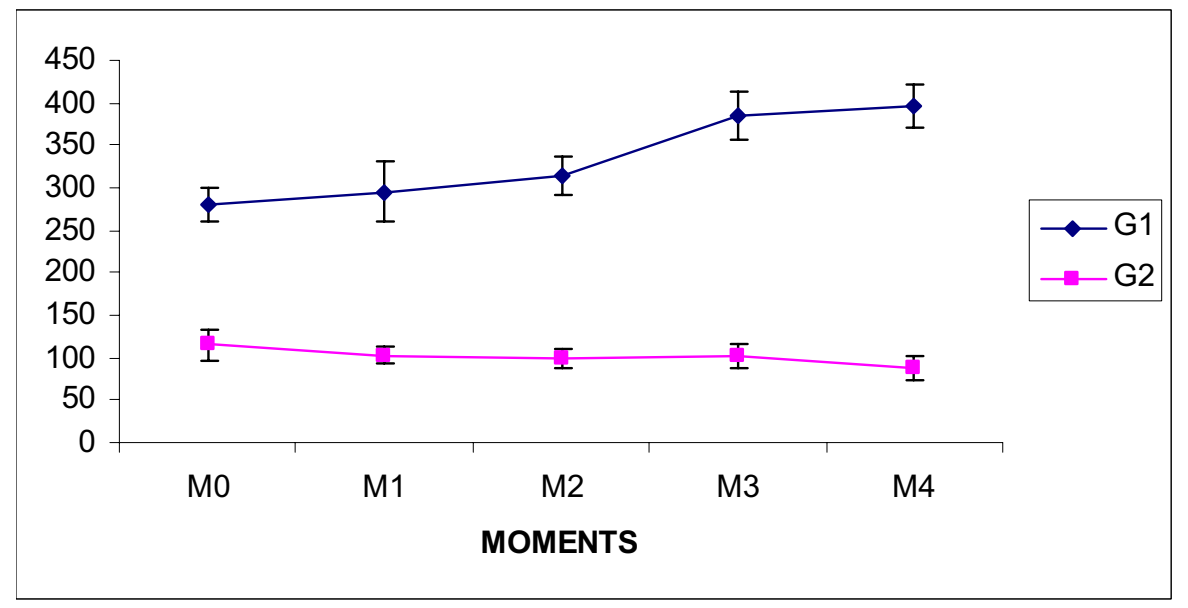

FIGURE 7 - Mean values for the rupture strength ( $g$ ) of samples for the ileal segment in the two groups at the experimental moments

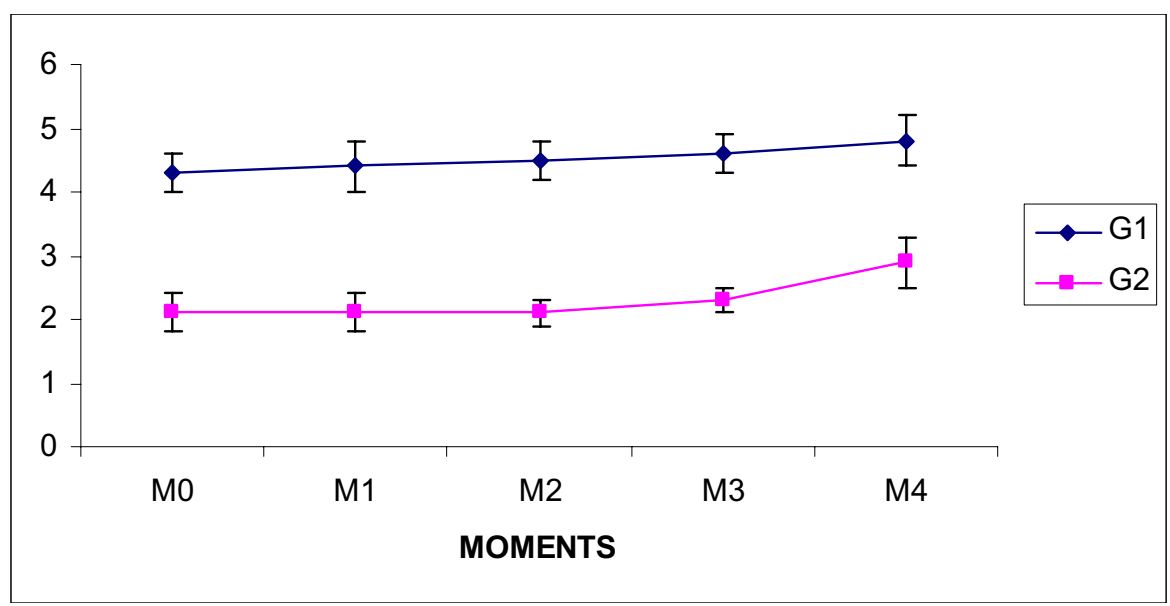

FIGURE 8 - Mean values for the rupture strength (g) of samples for the distal colon in the two groups at the experimental moments 


\section{Discussion}

Rats are widely used in the experimental investigation of intestinal anastomosis cicatrization because they can easily reproduce major clinical and biochemical characteristics of privation conditions. Additionally, they are easily handled and provide low operational $\operatorname{cost}^{5-15}$.

The alterations detected in our undernourished animals, such as progressive weight loss, sleepiness, irritability and decrease in total serum albumin concentration, are similar to those described by other authors in experimental models for protein lack in rats ${ }^{1}$.

One of the important cicatrization-related aspects concerns the mechanical properties of the repair tissue that connects surgical wound edges, which must provide the necessary resistance so as not to rupture when the wound is submitted to the organism's common tensions. These physical properties can be evaluated in a laboratory by means of basic methods when muscular cavity organs are used. One method consists in the resistance to gaseous or liquid insuflation (strength and explosion), and another in the traction of opposing extremities (strength and rupture). In the present study we did not use the first method because, due to the characteristics of the intestinal wall, there could be false interpretations ${ }^{3}$.

Explosion strength measures the resistance of a cavitary organ's wall to the increase of pressure inside it until a punctiform or partial anastomosis rupture occurs. The distension may be caused by the insuflation of air or water, and the tension exerted on the intestinal wall is similar to that exerted on a cylinder (Tension $=$ Pressure x Radius - Laplace's Law), but since the intestinal wall is elastic, radius changes occur during insuflation. When intestinal anastomosis takes place, this site, which is undergoing remodeling, is less distensible, and if insuflation is performed, because this segment has a smaller radius, it will be submitted to more tension than an intact intestinal segment, which has greater elasticity. Hence, rupture of the intestinal wall affecting adjacent tissue to the anatomosis may occur ${ }^{2,6}$.

Nevertheless, rupture strength makes it possible to evaluate the resistance of anastomosis to opposing forces. For such type of measurement, an anastomosis segment or its whole extension is used ${ }^{2}$. Even so, various difficulties are found in this study, since the composition of the intestinal wall is not homogeneous; it is cylindrical and has tissue layers such as musculature and a small amount of collagen concentrated in the submucous layer. Depending on the technique used, the segments removed from the intestinal wall may suffer alterations in their mechanical properties and present more or less contraction, which may alter the reading of resistance to traction forces. For this reason, in order to manage or minimize intestinal-wall trauma, in our study, the intestinal segments were immersed in saline solution and papaverine hydrochloride and toothless clamps were used for seizing intestinal samples ${ }^{9}$.

Interesting data observed, as regards rupture strength values, were that the animals in group 1, regardless of their sacrifice day, showed normal control values for both the ileal segment and distal colon, which was different from what was observed for the undernourished animals, since they showed a mechanical resistance of the ileal segment and distal colon that was always lower than that of the control group at the different moments ${ }^{2,4,5,6}$.

We are in agreement with Hesp et al. ${ }^{3}$ in that intestinal cicatrization requires suitable amounts of collagen and that such amounts are directly related to resistance to mechanical forces. At this point of view that we became interested in quantifying collagen in surgical wounds in the various phases of development of our experiment, in the dosage of blood albumin rate, hydroxyproline and total protein in the tissue, and their interactions ${ }^{2-15}$.

Hydroxyproline is a aminoacid, structural component almost exclusive of the collagen and elastin. Due to such strict distribution, hydroxyproline concentration has been widely used in order to estimate tissue collagen.

In normal intestinal walls, there is a balance between collagen synthesis and lysis ${ }^{7}$. After the performance of anastomosis, homeostatic imbalance is likely to occur, and depending on the cicatrization development phase, the synthesis or lysis phenomena may prevail. Adequate balance between collagen synthesis and lysis is of great importance for the success of colon anastomosis. The defects observed in collagen metabolism may result in deficient cicatrization with a larger occurrence of anastomosis dehiscence ${ }^{5}$.

Our findings, with lower albumin, hydroxyproline and total protein levels suggest that the decrease in mechanical resistance loss in the ileal and colon segments may be correlated with the decrease in collagen formation as a result of the lack of protein, which is also observed by the variation in the hydroxyproline / protein ratio ${ }^{5}$. However, there is not an explanation for the greater alteration in the distal colon in relation to that in the ileal segment. To Ferreira et al. ${ }^{2}$, this could be correlated with the method used. Hydroxyproline dosage, when estimated by its concentration $(\mu \mathrm{m} / 100 \mathrm{mg}$ of fresh tissue), can provide an erroneous amount in relation to its real concentration. This fact would result from the dilution of its fraction by the edema during soaking in saline solution or even in its concentration increase through a dehydration process. Therefore, the greater the edema, the lower the hydroxyproline concentration rate in the intestinal segment, which induces errors in the interpretation of collagen rates and rupture strength ${ }^{6}$.

In order to prevent such technical errors we dosed, in addition to hydroxyproline, tissue protein concentration and the hydroxyproline / protein ratio in particular. Since hydroxyproline represents the extracellular part of the total protein component deriving from collagenous and non-collagenous fractions, this ratio makes it possible to quantify collagen without dilution influences resulting from edema, inflammatory infiltrate, fatty tissue or weight variation stemming from a surgical technique ${ }^{5-6}$.

Hence, it is indicated that decrease in collagen concentration would result of its lower synthesis due to decrease in protein supply, in addition it's probably to occur alterations in intra and extramolecular bonds of the collagen, with damage on the mechanical resistance of the intestinal wall ${ }^{2}$. Such correlation can be observed in this study, where there was a decrease in collagen concentration which was followed by a reduction in mechanical resistance in the ileum and distal colon ${ }^{8-9}$

We believe that the situation created in our experimental model, a protein restriction with lower tissue collagen formation, can be a paradigm for understanding alterations in the rupture strength of the intestinal wall inducing the onset of dehiscence and its resulting peritoneal complications. Such verification is extremely important in the extrapolation of such observations to human beings, and it's well worth, in our viewpoint, for understanding intestinal cicatrization, particularly in previously malnourished patients submitted to surgeries of the digestive system. 


\section{Conclusion}

Protein malnutrition induces the loss of mechanical resistance of the ileum and distal colon and may be associated with a smaller percentage of collagenous tissue formation in the intestinal wall.

\section{References}

1. Campana AO, Burini RC, Outa AY, Camargo JLV. Experimental protein deficiency in adult rats. Rev Bras Pesq Med Biol. 1975;8:221-6.

2. Ferreira MM, Scialom JM, Campos AD, Ramalho LLZ, Marchini JS, Feres O, Rocha JJR. Efeito da desnutrição na cicatrização de anastomoses colônicas: estudo experimental em ratos. Rev Bras Coloproctol 2006;26(3):239-43.

3. Hesp FLEM, Hendricks T, Lubbers EJC, Boer HHM. Wound healing in the intestinal wall: a comparison between experimental ileal and colonic anastomoses. Dis Colon Rectum. 1984;27(2):99-104.

4. Irvin TT, Golicher JC. Actiology of disruption of intestinal anastomoses. Br J Surg. 1973;60:461-4.

5. Jiborn K, Jiborn H, Zederfeldt B. Comparison of healing in the left colon and ileum: changes in collagen content and collagen synthesis in the intestinal wall after ileal and colonic anastomoses in the rat. Acta Chir Scand. 1985;151:537-41.

6. Leite CVS, Naresse LE, Kobaiasi S, Minossi JG, Burini RC, Curi PR, Hossne WS. Efeito da desnutrição protéica na anastomose do cólon distal no rato: estudo da força de ruptura e do colágeno tecidual. Acta Cir Bras. 1993;8:145-50.
7. Jiborn H, Ahonen J, Zederfeldt B. Healing of experimental colonic anastomoses: the effect of suture technique on collagen concentration in the colonic wall. Am J Surg. 1978;135:333-40.

8. Naresse LE. Estudo comparative da cicatrização das anastomoses em plano único e em dois planos, intestino delgado do cão, avaliação anatomopatológica, estudo da força de ruptura e da hidroxiprolina tecidual [Dissertação]. Botucatu: Faculdade de Medicina de Botucatu, Universidade Estadual de São Paulo; 1986.

9. Naresse LE, Mendes EF, Curi PR, Luchiari PH, Kobayasi S. Aparelho para medida da força de ruptura das anastomoses intestinais. Rev Hosp Clin Fac Med. 1987;42(5):204-8.

10. Hunt Tk, Hawley PR, Hale J, Goodson W, Thakral KK. Colon repair: the collagenous equilibrium. In: Hunt TK. Wound healing and wound infection: theory and surgical pratice. New York: Appleton; 1980. p. 153-9.

11. Lowry OH, Resobrough NJ, Farr AL, Randalu RJ. Protein neasurement with the folin phenol reagent. J Biol Chem. 1951;193:265-75.

12. Bergman I, Loxley R. The determination of hidroxiproline in urine hidrolysates. Clin Chim Acta. 1970;27:347-9.

13. Angeleli AYO, Burini RC, Oliveira JED. Padronização da metodologia para determinação das frações da hidroxiprolina urinária. Rev Bras Patol Clin. 1982;18:124-7.

14. Diamantino AB, Rahal SC, Grilo TP. Interferência da nutrição na resistência mecânica do cólon e comparação entre duas técnicas de sutura para a síntese de ceratomia em ratos. Arch Vet Sci. 2002;7(2):1-7.

15. Stromberg BV, Klein L. Collagen formation during the healing of colonic anastomoses. Dis Colon Rectum. 1982;25:301-4.

\section{Correspondence:}

Victor Nakajima

Botucatu Medical School

São Paulo State University (UNESP)

Department of Otorrinolaryngology, Head and Neck Surgery

Distrito de Rubião Júnior, $\mathrm{s} / \mathrm{n}$

18618-970 Botucatu - SP Brazil

Phone/Fax: (55 14)3811-6256 / 3811-6081

nakajima@,fmb.unesp.br

Conflict of interest: none

Financial source: none

Received: March 25, 2008

Review: May 21, 2008

Accepted: June 26, 2008

\section{How to cite this article}

Nakajima V. Kobayasi S, Naresse LE, Leite CVS, Curi PR, Montovani JC. Alterations in the intestinal wall due to protein malnutrition in rats: evaluation of the rupture strength and the tissue's collagen. Acta Cir Bras. [serial on the Internet] 2008 Sept-Oct;23(5).

Available from URL: http://www.scielo.br/acb

\section{*Color figures available from www.scielo.br/acb}

